Bioscientia Medicina: Journal of Biomedicine \& Translational Research

Journal Homepage: www.bioscmed.com

\title{
Relationship of Exclusive Breastfeeding with History of Acute Respiratory Infection (ARI) in Children Aged 0-24 Months in Siwalima Village in
}

\section{November 2021}

\section{Vica Natalia Gonga ${ }^{1 *}$}

${ }^{1}$ Faculty of Medicine, Universitas Hang Tuah Surabaya, Surabaya, Indonesia

\section{A R T I C L E I N F O \\ Keywords: \\ Acute respiratory infection \\ Breastfeeding \\ Children \\ *Corresponding author: \\ Vica Natalia Gonga \\ E-mail address: vicagonga@yahoo.com}

The author has reviewed and approved the final version of the manuscript.

\section{https://doi.org/10.37275/bsm.v6i2.450}

\begin{abstract}
A B S T R A C T
Background. Acute respiratory infection (ARI) is a respiratory infection that affect both upper or lower respiratory tracts. The virus or bacteria causes ARI which lasts for 14 days. Indonesia had the highest mortality rate for ARI, in 2008 around $36.4 \%$ children infected; in 2009 around $32.1 \%$; in 2010 around $18.2 \%$; and in 2011 around $38.8 \%$. The prevalence of ARI in Siwalima Health Center around 3240 children in 2020. Breastfeeding has huge benefit for both moms and babies. The prevalence of breastfeeding in Indonesia is $66.1 \%$, but there are two provinces, West Papua $(34 \%)$ and Maluku (37.2\%) that have not reach the target yet. The purpose of this study is to find out if there is a relationship between Exclusive breastfeeding with history of Acute Respiratory Infection (ARI) in children in November 2021 in Siwalima Village, Aru Island, Maluku. Methods: This study uses observational analytical research methods, and cross- sectional design. The subject of this study are children age 0 24 months and lived in Siwalima Village. The sample of this study is using total sampling technic and there are 186 respondents. Questioners with yes or no answer are using in this study. Results: The result of chi-square test showed that there was a relationship between Exclusive breastfeeding with history of Acute Respiratory Infection (ARI) in children in November 2021 in Siwalima Village, Aru Island, Maluku. There are 84 respondent (45.2\%) had ARI and 102 respondent (34.8\%) didn't, also 91 respondents $(48.9 \%)$ didn't receive exclusive breastfeeding and 95 respondent receive exclusive breastfeeding. Conclusion: Breastfeeding can be increased, especially for children aged $0-6$ months in order to prevent infection.
\end{abstract}

\section{Introduction}

Indonesia is a tropical area that has a high potential for the occurrence of several infectious diseases that can pose a threat to public health. The increase in cases and deaths due to ARI has a close relationship with the consequences of environmental pollution caused by smoke due to forest fires, exhaust gases originating from transportation facilities, indoor air pollution due to kitchen smoke, cigarette smoke, and climate change such as changes in air temperature, humidity, and rainfall. ${ }^{1}$ One of the public health problems in developed and developing countries is Acute Respiratory Infection (ARI) because it can cause high infant and toddler mortality, namely 1 in 4 deaths that occur. ${ }^{2}$ Acute Respiratory Tract Infection (ARI) is an acute respiratory infection that attacks the upper and lowers respiratory tract. ARI itself is caused by a virus or bacteria and lasts for 14 days, and is characterized by one or more symptoms such as painful swallowing, runny nose, dry cough, or phlegm. According to WHO, ARI is the main cause of death from infectious diseases in the world, especially in developing countries. ARI is the main cause of treatment or consultation for children in hospitals or health centers. Data according to the Ministry of Health in 2012 that in Indonesia ranks first cause of infant mortality due to acute respiratory infections. A total of 
$36.4 \%$ infant mortality in $2008 ; 32.1 \%$ in $2009 ; 18.2 \%$

in 2010 and $38.8 \%$ in 2011. Based on data from the Siwalima Health Center itself in 2020 it is known that the incidence of ARI is the number one disease in most children, namely, around 402 aged 0-1 years, 1082 children aged 0-1 1-5 years, and 1756 children aged > 5 years. ${ }^{3-5}$

Risk factors that can cause ARI in children are unhealthy environmental factors (lack of air circulation, children are exposed to cigarette smoke), incomplete immunizations in children, low birth weight, lack of nutrition in children so that the immune system is not optimal, level of low parental education, gender and children do not get exclusive breastfeeding. Breast milk has a protective effect that tends to help reduce morbidity in children in the early months of birth. Based on the research, it was stated that the incidence of ARI was 4.96 times greater in children who did not receive exclusive breastfeeding compared to children who received exclusive breastfeeding. ${ }^{6.7}$ ASI (Mother's Milk) is a food that contains nutrients needed by children to help increase the child's immune system from various infections. Breast milk is a source of nutritional intake for newborns, which is exclusive, namely by giving it to infants aged 0-6 months without being given any additional food. ${ }^{8-10}$

In Indonesia in 2020, of the number of infants aged less than 6 months who received exclusive breastfeeding, around $66.1 \%$. The achievement indicator of the percentage of infants aged less than 6 months who are getting exclusive breastfeeding has met the 2020 target, which is $40 \%$. However, based on the provincial distribution, as many as 32 provinces have achieved the expected target and there are still 2 provinces that did not reach the target, namely West Papua (34\%) and Maluku (37.2\%). Breastfeeding is very beneficial for babies, mothers, and socio-economically. According to research, breastfeeding can reduce the incidence of infections that often occur in infants such as ARI, diarrhea, otitis media, and urinary tract infections so that breastfeeding plays a very important role in reducing infant mortality. Breast milk contains an immune substance, namely lactoferrin which is a protein in breast milk that functions to prevent bacterial infections from infections caused by bacteria, viruses, fungi, and others. In addition to lactoferrin, breast milk also contains substances that are immune to other infections such as oligosaccharides, immunoglobulin A and antibodies. ${ }^{11}$

\section{Methods}

The research design is an analytical observational with a cross-sectional design which was carried out in the Siwalima Village, Aru Islands, Maluku in November 2021. This study sought the relationship between exclusive breastfeeding and a history of acute respiratory infection (ARI) in children aged 0-24 months in the Siwalima village by having the independent variable (exclusive breastfeeding) and the dependent variable (incidence of ARI). The subjects of this study were all children aged 0-24 months who were in the Siwalima Village, Aru Islands in November 2021, totaling 186 people. Sampling in this study using a total sampling technique.

Collecting data from research subjects using primary data obtained from interviews with parents of research subjects. Primary data explored were sociodemographic data, frequency of exclusive breastfeeding, and history of ARI incidence. Furthermore, data analysis was carried out using SPSS version 25 software. First, a univariate analysis was carried out which presented the frequency distribution. Furthermore, a bivariate analysis was performed to see the relationship between exclusive breastfeeding and the history of the incidence of ARI with chi-square, $\mathrm{p}<0.05$. 


\section{Results}

Table 1. Distribution of samples by age

\begin{tabular}{|c|c|c|}
\hline Children's Age & Frequency & $\%$ \\
\hline $0-6$ months & 101 & 54.3 \\
$7-13$ months & 57 & 30.6 \\
$14-20$ months & 17 & 9.1 \\
$21-24$ months & 11 & 5.9 \\
\hline Total & 186 & 100 \\
\hline
\end{tabular}

Table 1 shows the distribution of samples based on Maluku, which is dominated by the age of 0-6 months, the age of children in Siwalima Village, Aru Islands, as many as 101 respondents (54.3\%).

Table 2. Distribution of samples based on gender

\begin{tabular}{|c|c|c|}
\hline Gender & $\mathrm{N}$ & $\%$ \\
\hline Male & 93 & 50 \\
Female & 93 & 50 \\
\hline Total & 186 & 100 \\
\hline
\end{tabular}

Table 2 shows the distribution of the sample based on the sex of children residing in the Siwalima Village, sexes between female and male - the same male, namely 93 respondents (50\%).

Aru Islands, Maluku, which obtained the number of

Table 3. Distribution of the frequency of exclusive breastfeeding

\begin{tabular}{|c|c|c|}
\hline Gender & $\mathrm{N}$ & $\%$ \\
\hline $\begin{array}{c}\text { Exclusive Breastfeeding } \\
\text { Not Exclusively Breastfeeding }\end{array}$ & 95 & 51.1 \\
\hline Total & 186 & 48.9 \\
\hline
\end{tabular}

Table 3 shows that from 186 respondents the results were not too much difference between children who were given exclusive breastfeeding, namely 95 respondents (51.1\%) and those who did not receive exclusive breastfeeding were 91 respondents (48.9\%).

Table 4. Frequency distribution of history of ARI

\begin{tabular}{|c|c|c|}
\hline Gender & $\mathrm{N}$ & $\%$ \\
\hline No ARI & 102 & 54.8 \\
ARI & 84 & 45.2 \\
\hline Total & 186 & 100 \\
\hline
\end{tabular}

Table 4 shows that from 186 respondents, 102 those who had ARI were 84 respondents (45.2\%). respondents (54.8\%) did not experience ARI, while 
Table 5. The relationship between breastfeeding exclusion and history of ARI

\begin{tabular}{|c|c|c|c|c|c|}
\hline \multirow{2}{*}{$\begin{array}{c}\text { Breastfeeding } \\
\text { Exclusive }\end{array}$} & \multicolumn{3}{|c|}{ History of ARI } & \\
\cline { 2 - 6 } & \multicolumn{2}{|c|}{ Not ARI } & Frequency & \% value * \\
\cline { 2 - 6 } & Frequency & $\%$ & 14 & 14.7 & 0.001 \\
\hline $\begin{array}{c}\text { Exclusive breastfeeding } \\
\begin{array}{c}\text { Not Exclusive } \\
\text { breastfeeding }\end{array}\end{array}$ & 81 & 85.3 & 70 & 76.9 \\
\hline Total & 102 & 23.1 & 84 & 45.2 & \\
\hline
\end{tabular}

${ }^{*}$ Chi-square, $\mathrm{p}<0.05$.

Table 5 shows the results of the analysis of the relationship between exclusive breastfeeding and history of ARI obtained by 14 respondents (14.7\%), while those who were given exclusive breastfeeding but not ARI were 81 respondents (85.3\%). There was a significant relationship between exclusive breastfeeding and the history of ARI, $\mathrm{p}<0.05$.

\section{Discussion}

Acute Respiratory Infection (ARI) is characterized by symptoms of fever followed by cough or runny nose that lasts no more than 10 days and requires treatment. ARI also attacks children under the age of 5 years, especially more in boys than girls. The results of this study are in line with the study in which 96 respondents found that 50 respondents (52.1\%). ${ }^{12.13}$ The results also showed that from 186 respondents, 91 respondents (48.9\%) did not give exclusive breastfeeding, while 95 respondents (51.1\%). Exclusive breastfeeding is breastfeeding alone without additional fluids for 6 months. Breastfeeding for children has various benefits, such as it containing complete nutrition that helps increase the body's resistance to help protect against allergies, infectious diseases such as otitis media, diarrhea, or respiratory tract diseases; improve mental and emotional intelligence; and helps provide stimulation to the nerves and intelligence development. ${ }^{14}$ The results of this study are in line with research which states that children who are not exclusively breastfed have a 4.79 times greater risk of developing ARI than children who are exclusively breastfed. ${ }^{15,16}$

Breast milk itself consists of various substances, namely secretory IgA, lactoferrin, -lactalbumin, oligosaccharides and glycoconjugates. In addition, breast milk also contains various hormones, cytokines, chemokines, growth factors and so on. The secretory IgA contained in breast milk can protect babies from the dangers of infection with germs such as Campylobacter, Shigella, Escherichia coli and Giardia lamblia. In addition, oligosaccharides have an anti-adrenergic effect which plays a role in preventing infection with Haemophilus influenza and Streptococcus pneumonia which are the most common bacteria causing ARI by preventing the attachment of bacteria to receptors on mucous membranes. Breast milk also functions to prevent acute and recurrent otitis media which is one part of ARI. This research is also in line with studies that state that exclusive breastfeeding for the first 6 months is protective for the development of respiratory tract infections in infants and as a reduction in the risk of lower respiratory tract infections after the baby is 4 years old.18-20

\section{Conclusion}

There is a relationship between exclusive breastfeeding and history of ARI occurrence in Siwalima Village, Aru Island, Maluku in November 2021.

\section{References}

1. Duijts L, Jaddoe VWV, Hofman A, Moll HA. Prolonged and exclusive breastfeeding reduces the risk of infectious diseases in infancy. Pediatrics. 2010; 126: e18-25. doi: 10.1542/peds.2008-3256

2. Wright AL, Taussig LM, Ray CG, Harrison HR, Holberg CJ. The tucson children's respiratory study. II Lower respiratory tract illness in the first year of life. Am J Epidemiol. 1989; 129: $1232-46$. 
3. Neuspiel DR, Rush D, Butler NR, Golding J, Bijur PE, Kurzon M. Parental smoking and postinfancy wheezing in children: a prospective cohort study.AmJ Public Health. 1989; 79: 16871. doi: 10.1016/j.prrv.2016.08.005

4. Quigley MA, Kelly YJ, Sacker A. Breastfeeding and hospitalization for diarrheal and respiratory infection in the United Kingdom Millennium Cohort Study. Pediatrics. 2007; 119: e837-42. doi: 10.1542/peds.2006-2256

5. Williams BG, Gouws E, Boschi-Pinto C, Bryce J, Dye C. Estimates of world-wide distribution of child deaths from acute respiratory infections. Lancet Infected Dis. 2002; 2: 25-32. doi: 10.1016/S1473-3099(01)00170-0

6. Morikawa S, Hiroi S, Kase T. Detection of respiratory viruses in gargle specimens of healthy children.J Clin Virol. 2015; 64: 59-63. doi: $10.1016 / j . j c v .2015 .01 .006$

7. Leowski J. Mortality from acute respiratory infections in children under 5 years of age: global estimates. World Health Stat Q Rapport Trimestriel De Statistiques Sanitaires Mondiales. 1986; 39:138-44.

8. Koopman LP, Smit HA, Heijnen ML, Wijga A, van Strien RT, Kerkhof M, et al. Respiratory infections in infants: interaction of parental allergy, childcare, and siblings-The PIAMA study. Pediatrics. 2001; 108: 943-8. doi: 10.1542/peds. 108.4 .943

9. Baker D, Taylor H, Henderson J. Inequality in infant morbidity: causes and consequences in England in the 1990s. J Epidemiol Commun. Health. 1998; 52: 451-8.

10. Bhutta ZA, Ahmed T, Black RE, Cousens S, Dewey K, Giugliani E, et al. What works? Interventions for maternal and child undernutrition and survival.Lancet. 2008; 371: 417-40. doi: 10.1016/S0140-6736(07)61693-6

11. Hanieh S, Ha TT, Simpson JA, Thuy TT, Khuong NC, Thoang DD, et al. Exclusive breastfeeding in early infancy reduces the risk of inpatient admission for diarrhea and suspected pneumonia in rural Vietnam: a prospective cohort study. BMC Public Health. 2015; 15: 9. doi:10.1186/s12889-015-2431-9

12. Ajetunmobi OM, Whyte B, Chalmers J, Tappin DM, Wolfson L, Fleming M, et al. Breastfeeding is associated with reduced childhood hospitalization: evidence from a Scottish birth cohort (1997-2009). $J$ Pediatrics. 2015; 166: 620-625.e4. doi:10.1016/j.jpeds.2014.11.013

13. Dixon DL. The role of human milk immunomodulators in protecting against viral bronchiolitis and development of chronic wheezing illness. Children. 2015; 2: 289-304. doi: 10.3390/children2030289

14. Quigley MA, Carson C, Sacker A, Kelly Y. Exclusive breastfeeding duration and infant infection.Eur J Clin Nutr. 2016; 70: 1420-7. doi: 10.1038/ejcn.2016.135

15. Lamberti LM, Zakarija-Grkovi I, Fischer Walker CL, Theodoratou E, Nair H, Campbell H, et al. Breastfeeding for reducing the risk of pneumonia morbidity and mortality in children under two: a systematic literature review and meta-analysis. BMC Public Health. 2013; 13: S18. doi: 10.1186/1471-2458-13-S3-S18

16. Paricio Talayero JM, Lizán-García M, Otero Puime A, Benlloch Muncharaz MJ, Beseler Soto B, Sánchez-Palomares $\mathrm{M}$, et al. Full breastfeeding and hospitalization as a result of infections in the first year of life.Pediatrics. 2006; 118: e92-99. doi: 10.1542/peds.20051629

17. Chantry CJ. Full breastfeeding duration and associated decrease in respiratory tract infection in US Children. Pediatrics. 2006; 117: 425-32. doi: 10.1542/peds.2004-2283

18. Tromp I, Kiefte-de Jong J, Raat H, Jaddoe V, Franco O, Hofman A, et al. Breastfeeding and the risk of respiratory tract infections after infancy: the Generation R Study.PLOS ONE. 2017; 12: e0172763. doi: 10.1371/journal.pone.0172763

19. Yamakawa $\mathrm{M}$, Yorifuji $\mathrm{T}$, Kato $\mathrm{T}$, Inoue $\mathrm{S}$, Tokinobu A, Tsuda T, et al. Long-term effects of breastfeeding on children's hospitalization for respiratory tract infections and diarrhea in early childhood in Japan. Maternal Child Health J. 
2015; 19: 1956-65. doi: 10.1007/s10995-015-

1703-4

20. Pandolfi E, Gesualdo F, Carloni E, Villani A, Midulla F, Carsetti R, et al. Does breastfeeding protect young infants from pertussis? Casecontrol Study and Immunological Evaluation. Pediatric Infect Dis J. 2017; 36: e48-e53. doi: 10.1097/INF.0000000000001418 